\title{
ALFALFA YIELD AND QUALITY AS FUNCTION OF NITROGEN FERTILIZATION AND SYMBIOSIS WITH Sinorhizobium meliloti
}

\author{
Wladecir Salles de Oliveira ${ }^{1 *}$; Patrícia Perondi Anchão Oliveira²; Moacyr Corsi³; Fábio Rodrigo \\ Sanches Duarte ${ }^{1}$; Siu Mui Tsai ${ }^{1}$ \\ ${ }^{1}$ USP/CENA - Lab. de Biologia Celular e Molecular, C.P. 96 - 13.400-970 - Piracicaba, SP - Brasil. \\ Embrapa Gado de Leite - Núcleo Sul - FZEA/USP, C.P. 23, 13.635-900 - Pirassununga, SP \\ ${ }^{3}$ USP/ESALQ - Depto. de Zootecnia, C.P. 9 - 13418-900 - Piracicaba, SP - Brasil. \\ *Corresponding author <wsolivei@esalq.usp.br>
}

\begin{abstract}
The efficiency of the symbiotic process between alfalfa (Medicago sativa L.) and Sinorhizobium meliloti can be drastically affected by soil nitrogen. This research evaluates how mineral fertilization affects the contribution of symbiosis to the yield and quality of alfalfa in two experiments under controlled conditions, and a third one in the field. Under controlled conditions, positive effect of nitrogen fertilizer was observed, whereas, in the field, negative effect of the mineral nitrogen ( $\left.450 \mathrm{~kg} \mathrm{ha}^{-1} \mathrm{year}^{-1}\right)$ on the symbiotic process was observed, with reduction of nodulation and nitrogenase activity. However, there was no effect on yield, total nitrogen concentration, crude protein, non-protein nitrogen and digestibility in relation to the treatment without mineral N. The cultivars showed similar performance under different conditions, with 'Crioula Brasileira' and 'Crioula Chilena' showing the highest yield and 'Pioneer-5454' the highest forage nutritive value.

Key words: Medicago sativa L., biological nitrogen fixation
\end{abstract}

\section{PRODUÇÃO E QUALIDADE DE ALFAFA EM FUNÇÃO DA ADUBAÇÃO NITROGENADA E DA SIMBIOSE COM Sinorhizobium meliloti}

\begin{abstract}
RESUMO: A eficiência do processo simbiótico entre a alfafa (Medicago sativa L.) e a bactéria Sinorhizobium meliloti pode ser afetada pela presença de nitrogênio no solo. Avaliou-se a contribuição da simbiose em comparação à adubação nitrogenada em componentes da produção de alfafa, em dois experimentos sob condições controladas e um terceiro em campo. Sob condições controladas, verificou-se efeito positivo da adubação nitrogenada sobre as variáveis estudadas, sobre a produção de matéria seca, teor de nitrogênio e proteína. Em campo, verificou-se efeito negativo do $\mathrm{N}$-mineral (450 $\mathrm{kg} \mathrm{ha}^{-1}$ ano $^{-1}$ ) sobre o processo simbiótico, com redução da nodulação e atividade da enzima nitrogenase, sem efeito sobre a produção de matéria seca, nitrogênio total, proteína bruta, nitrogênio não protéico e digestibilidade. O desempenho dos cultivares estudados foi semelhante nos dois ambientes de estudo, sendo os cultivares Crioula Brasileira e Crioula Chilena os mais produtivos e o cultivar Pioneer-5454 como o de melhor valor nutritivo da biomassa produzida. Adubação nitrogenada é dispensável para Medicago sativa inoculada com a bactéria fixadora de nitrogênio correspondente, uma vez que a simbiose pode garantir o fornecimento de nitrogênio em quantidade suficiente para a produção.
\end{abstract}

Palavras-chave: Medicago sativa L., fixação biológica do nitrogênio

\section{INTRODUCTION}

Nitrogen supply through mineral fertilization affects nitrogen biological fixation process in legume plants, even though plants can directly absorb the mineral N. For species such as alfalfa, in addition to the inhibitory effect, mineral fertilization decreases the useful life of the crop and the quality of protein in the dry matter (Cihacek, 1994). The interaction alfalfa/Sinorhizobium meliloti is one of the most efficient interactions between nitrogen fixing bacteria of the genera Brady or Sino rhizo- bium and legume plants. The potential for nitrogen fixation via symbiosis is supposed to be, in average, $450 \mathrm{~kg}$ ha $^{-1}$ year $^{-1}$ (Fishbeck et al., 1987). In the United States, the leader alfalfa world producer, the $\mathrm{N}$-fixation values varies between 120 and $250 \mathrm{~kg} \mathrm{ha}^{-1}$ year $^{-1}$ in 2 to 6 cuts per year (Zhu et al., 1996), while in Argentina, varies from 200 to $650 \mathrm{~kg} \mathrm{ha}^{-1}$ year ${ }^{-1}$ in up to 7 cuts per year (Racca et al., 1998).

Alfalfa is considered an excellent nitrogen extractor, mostly in the form of nitrate. The use of nitrogen fertilizers is thus not recommended in alfalfa crops because 
of their capacity to form effective abundant, nodules that can promote efficient nitrogen fixation (Rasse \& Smucker, 1999). According to Fontes et al. (1992) and Raun et al. (1999), there is a positive response in biomass production for $\mathrm{N}$ application only in excess of 100 $\mathrm{kg} \mathrm{ha}^{-1}$ year $^{-1}$. At these rates, the nitrogen added to the soil is preferentially absorbed and can negatively affect root nodule formation (Bekbulatov et al., 1998), nodule size and weight (Zhu et al., 1998) and, as a consequence, the symbiotic process efficiency. The need for a large nitrogen fertilizer quantity to guarantee satisfactory alfalfa production, besides costs increase, can negatively influence the environment (Stout et al., 2000), in the form of sub-surface water contamination resulting from nitrate lixiviation, when fertilizer is applied in great amounts and shortly spaced.

This work studied the effect of the nitrogen fertilization on alfalfa yield and quality, both in greenhouse and in the field cultivation conditions.

\section{MATERIAL AND METHODS}

Three experiments were carried out at Piracicaba, State of São Paulo, Brazil: two under controlled conditions (greenhouse), from January to May 1998, and one in the field, from July 1997 to May 1998.

\section{Experiment 1 - Nitrogen levels in nutrient solution in the presence of Sinorhizobium meliloti}

Alfalfa seeds cultivar 'Crioula' were sown in 0.3L Leonard pots (Vincent, 1975), filled with sand and vermiculite (1:1, v:v) and nutrient solution (Sarruge, 1975). Five days after sowing, pots were inoculated with $1 \mathrm{~mL}$ of YM (Manitol-Yeast Extract) liquid medium containing SEMIA-116 (FEPAGRO, Porto Alegre, Brazil) strain of Sinorhizobium meliloti, in the concentration of $2.32 \times 10^{9}$ UFC $\mathrm{mL}^{-1}$. The experiment was set up in randomized, complete blocks $(\mathrm{n}=5)$ and seven treatments (nitrogen rates: $0,1,2,4,6,8,16 \mathrm{mmol} \mathrm{L}^{-1}$, as $\mathrm{NH}_{4} \mathrm{NO}_{3}$ ). Forty-two days after sowing the aerial part of the plants were cut $3 \mathrm{~cm}$ above substrate surface, stored in paper bags, and oven dried at $60^{\circ} \mathrm{C}$ for 72 hours. The root system was stored in 500-mL vials for nitrogenase activity evaluation (Hardy et al., 1968), and afterwards rinsed for nodule counting.

Experiment 2 - Biological $\mathrm{N}_{2}$ fixation and nitrogen fertilization effects on several alfalfa cultivars under greenhouse conditions

An experiment was set up with treatments distributed in a randomized factorial design, with four replications. Performance of 'Crioula Chilena', 'Crioula Brasileira', 'CUF-101' and 'Pioneer 5454' cultivars in response to nitrogen fertilizer rates (2 and $16 \mathrm{mmol} \mathrm{L}^{-1}$ of $\mathrm{N})$ was evaluated, based on the number of nodules, nitrogenase activity, dry matter production, number of stems, nitrogen content and crude protein.
Previously disinfested seeds were sown in 1.5-L Leonard pots filled with sand and vermiculite (1:1, v:v) and nutrient solution (Sarruge, 1975) with 2 and $16 \mathrm{mmol}$ $\mathrm{L}^{-1}$ of $\mathrm{N}$ as $\mathrm{NH}_{4} \mathrm{NO}_{3}$. Five days after sowing pots were inoculated with $1 \mathrm{~mL}$ of liquid medium YM with SEMIA116 Sinorhizobium meliloti strain, in the concentration of $3.50 \times 10^{9} \mathrm{UFC} \mathrm{mL}^{-1}$. The experiment was evaluated at 40 days after germination and every 35 days from the first sampling. At each harvest, plant stems were counted, cut, stored in paper bags, and oven dried for 72 hours at $60^{\circ} \mathrm{C}$. Dry matter (DM) was then weighed, milled and homogenized for nitrogen, crude protein, non-protein nitrogen content, and in vitro digestibility determinations, according to procedures described by Pereira Jr. \& Rossi Jr. (1990). The root system was disposed in $500 \mathrm{~mL}$ vials for nitrogenase activity analysis (Hardy et al., 1968) and there after rinsed for nodule evaluation.

\section{Experiment 3 - Biological $\mathrm{N}_{2}$ fixation and nitrogen fer- tilization effects on field grown alfalfa cultivars}

The field experiment was carried out in

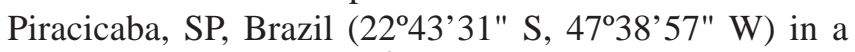
factorial design, in $5.0 \mathrm{~m}^{2}(1.0 \mathrm{~m} \times 5.0 \mathrm{~m})$ plots distributed in randomized, complete blocks $(n=4)$. The effects of alfalfa cultivars ('Crioula Chilena', 'Crioula Brasileira', 'CUF-101' and 'Pioneer 5454') and nitrogen fertilization (presence or absence) were evaluated, based on the number of nodules, nitrogenase activity, dry matter production, number of stems, total nitrogen, crude protein, non-protein nitrogen and DM digestibility. The chemical soil characteristics prior to experiment set up were: $\mathrm{pH}\left(\mathrm{CaCl}_{2} 0.01 \mathrm{~mol} \mathrm{~L}^{-1}\right) 5.1 ; 49 \mathrm{mg} \mathrm{dm}^{-3} \mathrm{P}$ (resin); $26 \mathrm{~g} \mathrm{dm}^{-3}$ O.M.; 1.3; 42; 7; 28 and $1 \mathrm{mmol}_{\mathrm{c}} \mathrm{dm}^{-3}$ of K, Ca, $\mathrm{Mg}, \mathrm{H}+\mathrm{Al}$ and $\mathrm{Al}$, respectively; $\mathrm{CTC}=78 \mathrm{mmol}_{\mathrm{c}} \mathrm{dm}^{-3}$ and $\mathrm{V}=64 \%$. Soil liming and fertilization were provided with the addition of $2.34 \mathrm{Mg} \mathrm{ha}^{-1}$ of dolomitic limestone $($ ECC $=85), 60 \mathrm{~kg} \mathrm{ha}^{-1} \mathrm{P}_{2} \mathrm{O}_{5}$ as ordinary superphosphate, $72 \mathrm{~kg} \mathrm{ha}^{-1} \mathrm{~K}_{2} \mathrm{O}$ as KCl, $30 \mathrm{~kg} \mathrm{ha}^{-1}$ FTE BR 12 and $250 \mathrm{~g}$ $\mathrm{ha}^{-1} \mathrm{Mo}$ as sodium molybdate. Nitrogen fertilization was intended to reach $450 \mathrm{~kg} \mathrm{~N} \mathrm{ha}^{-1}$ year $^{-1}$ in ten applications as suggested by Monteiro et al. (1998). From January 1998 forth, four cuts were performed, totalizing the application of $180 \mathrm{~kg} \mathrm{~N} \mathrm{ha}^{-1}$ in the urea form.

Water was supplied through sprinkler irrigation and the applied quantity determined by tensiometers installed within the experiment. Weed control was done manually. Pest and disease control was made once by the application of the insecticide 'Ivermectin' together with the fungicide 'Mancozeb'. Two sub-samples of $0.1 \mathrm{~m}^{2}$ were collected within each plot, shoots were cut above the soil surface and packed in paper bags. All aerial parts were oven dried for 72 hours at $60^{\circ} \mathrm{C}$. After drying, samples were ground, homogenized and analyzed for nitrogen content, crude protein, non-protein nitrogen and digestibility (Pereira Jr. \& Rossi Jr., 1990). Micro-plots 
were assigned exclusively for the collection of destructive samples. Root systems of four plants of each cultivar and from each nitrogen level were separated of the aerial part and disposed in $500 \mathrm{~mL}$ vials for nitrogenase analysis (Hardy et al., 1968). In the sequence the root system was rinsed for nodule evaluation.

The program SAS (SAS, 1985) was used for the statistical analysis routine. Data were submitted to analysis of variance (test F) followed by Tukey's test for mean comparisons. Regression analyses as well as significance levels were determined by the " $\mathrm{t}$ " test using the SANEST program (Sárries et al., 1993).

\section{RESULTS AND DISCUSSION}

\section{Nitrogen levels in nutrient solution in the presence of Sinorhizobium meliloti}

Legume plants need nitrogen for maintenance during initial germination, before the atmospheric nitrogen fixation process effectively begin; this $\mathrm{N}$ is supplied first by the seed and thereafter by the soil (Teuber et al., 1984). The small size of alfalfa seeds turns indispensable in that phase supplying the soil nitrogen. In the greenhouse experiment, the number of formed nodules presented small variation in the nitrogen range from 1 to 8 mmol L ${ }^{-1}$ (Figure 1). The absence or $16 \mathrm{mmol} \mathrm{L}^{-1}$ of nitrogen in solution affected negatively the nodulation $(P$ $>0.05$ ), because of reduced plant growth in the nitrogen absence and probably no nodules formation in the presence of abundant nitrogen in solution in the $16 \mathrm{mmol} \mathrm{L}^{-1}$ treatment. Determination of acetylene reduction nitrogenase activity allows the indirect evaluation of the $\mathrm{N}_{2}$ fixation process. That method can be used with success to check the enzyme activity level in relation to other factors in study (Hardy et al., 1968). In the present study, higher nitrogenase activity was found in the $2 \mathrm{mmol} \mathrm{L}^{-1}$ of $\mathrm{N}$ treatment, with accentuated reduction as nitrogen was added to the nutrient solution. Dry matter production responded positively to the nitrogen increase with accentuated alfalfa growth up to $4 \mathrm{mmol} \mathrm{L}^{-1}$ of $\mathrm{N}$. As well

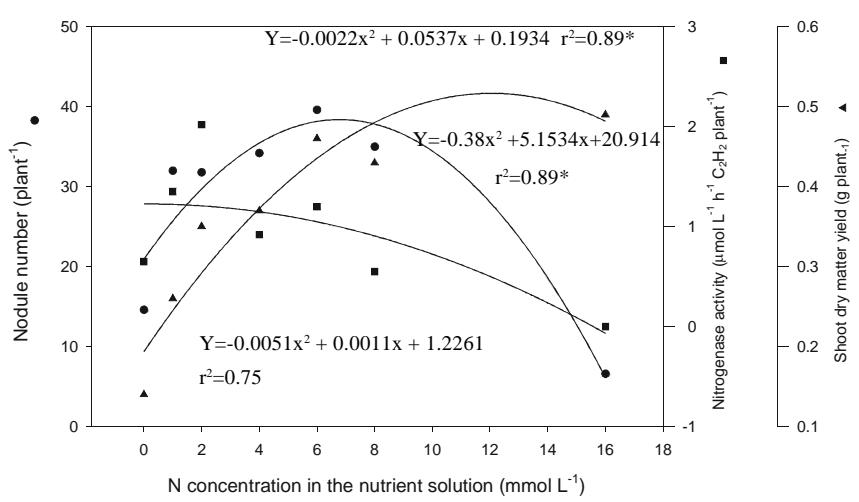

Figure 1 - Shoot dry matter yield (SDM), number of nodules and nitrogenase activity ( $\mathrm{N}$-ase) in alfalfa plants grown with rates of nitrogen in nutrient solution. as for other legume species, the initial concentration of $2 \mathrm{mmol} \mathrm{L}^{-1}$ of $\mathrm{N}$ was enough for conditioning of nitrogen symbiosis and biological fixation process for alfalfa (Figure 1). According to Cihacek (1994), independent of nitrogen concentration in the soil, a 17 to $28 \mathrm{~kg} \mathrm{ha}^{-1}$ of mineral $\mathrm{N}$ fertilization for alfalfa establishment benefits the plant until the symbiosis is established, but this fertilization might be dispensed because of the high alfalfa ability in extracting existing soil nitrogen.

Increases in the nitrogen biological fixation $(P>$ 0.05) are not often observed under field conditions (Teuber et al., 1984), what might be a consequence of satisfactory nitrogen levels in the soil (Phillips et al., 1982). In high nitrogen soils, even when properly inoculated, alfalfa plants do not form nodules until the soil nitrogen content is reduced (Anchão, 1995). When Sinorhizobium meliloti is not in symbiosis with legume plants, it survives in the saprophytic form in the soil. Thus, the greater the soil organic matter content, the greater will be the possibilities of energy acquirement (Araújo \& Hungary, 1994). Taking into account that most Brazilian soils are poor in organic matter, it is common to find good nodulation only when the seed inoculation is adequately performed, even in subsequent legume plantings.

\section{Biological $\mathbf{N}_{2}$ fixation and nitrogen fertilization in sev- eral alfalfa cultivars under greenhouse conditions}

There was no significant interaction among factors. Under low $\mathrm{N}\left(2 \mathrm{mmol} \mathrm{L}^{-1}\right)$ availability no differences were detected among the studied genotypes except for dry matter production (Table 1). 'CUF-101' presented lower dry mass accumulation than 'Crioula Chilena' and Crioula Brasileira' cultivars. Under high $\mathrm{N}\left(16 \mathrm{mmol} \mathrm{L}^{-1}\right)$ availability an increase in dry matter production $(P>0.05)$, nitrogen content and crude protein was observed as compared to the lower $\left(2 \mathrm{mmol} \mathrm{L}^{-1}\right) \mathrm{N}$ availability. Nodulation has its own gene regulation that is initiated by the symbiotic agent recognition of the root secondary exudates compounds (Phillips et al., 1994). In the presence of nitrogen, the recognition mechanism is interrupted by the plant as a form of energy saving and protection against the attack of pathogenic microorganisms that use the same process to infect the roots (Spaink, 1992).

\section{Biological $\mathrm{N}_{2}$ fixation and nitrogen fertilization effects on field grown alfalfa cultivars}

There were no interactions among the evaluated factors $(P>0.05)$. No differences among cultivars were detected in respect to nodule number and enzyme nitrogenase activity, corroborating the results already obtained under greenhouse conditions (Table 2). Nevertheless, the application of $45 \mathrm{~kg} \mathrm{~N}^{-1}$ after each cut interfered in the nodule infection and formation process and in the enzyme activity $(P>0.05)$. The acetylene reduction analysis, besides demonstrating the nitrogenase activity, can be 
Table 1 - Dry matter yield (DM), nitrogenase activity (N-ase), number of nodules per plant (NN), nitrogen concentration (N) and crude protein (CP) of alfalfa plants grown in the greenhouse (average of four replications and four samplings).

\begin{tabular}{|c|c|c|c|c|c|}
\hline & $\mathrm{DM}$ & $\mathrm{N}-\operatorname{ase}^{(1)}$ & $\mathrm{NN}^{1}$ & $\mathrm{~N}$ & $\mathrm{CP}$ \\
\hline & g plant $^{-1}$ & $\mu \mathrm{mol} \mathrm{L} \mathrm{L}^{-1} \mathrm{~h}^{-1}$ plant $^{-1}\left(\mathrm{C}_{2} \mathrm{H}_{2}\right)$ & - n & $---\%$ & (n) \\
\hline \multicolumn{6}{|l|}{ Cultivar } \\
\hline Crioula Brasileira & $8.77 \mathrm{a}$ & $12.04 \mathrm{a}$ & $287 \mathrm{a}$ & $3.41 \mathrm{a}$ & $21.3 \mathrm{a}$ \\
\hline Crioula Chilena & $8.44 \mathrm{a}$ & $13.44 \mathrm{a}$ & 245 a & $3.64 \mathrm{a}$ & $22.5 \mathrm{a}$ \\
\hline Pioneer-5454 & $8.32 \mathrm{ab}$ & $12.40 \mathrm{a}$ & $166 \mathrm{a}$ & $3.57 \mathrm{a}$ & $22.3 \mathrm{a}$ \\
\hline CUF-101 & $6.74 \mathrm{~b}$ & $14.79 \mathrm{a}$ & $234 \mathrm{a}$ & $3.40 \mathrm{a}$ & $21.2 \mathrm{a}$ \\
\hline $\operatorname{LSD}^{(2)}$ & 1.59 & 7.72 & 175 & 0.31 & 1.91 \\
\hline \multicolumn{6}{|l|}{ Nitrogen } \\
\hline $16 \mathrm{mmol} \mathrm{L}^{-1}$ of $\mathrm{N}$ & $8.76 \mathrm{a}$ & $\mathrm{SN}^{(3)}$ & $\mathrm{SN}$ & $3.85 \mathrm{a}$ & $23.9 \mathrm{a}$ \\
\hline $2 \mathrm{mmol} \mathrm{L}^{-1}$ of $\mathrm{N}$ & $7.39 \mathrm{~b}$ & $\mathrm{SN}$ & $\mathrm{SN}$ & $3.15 \mathrm{~b}$ & $19.7 \mathrm{~b}$ \\
\hline $\operatorname{LSD}^{(2)}$ & 0.84 & & & 0.16 & 1.01 \\
\hline $\mathrm{CV} \%$ & 14.36 & 27.89 & 35.70 & 6.42 & 6.33 \\
\hline
\end{tabular}

${ }^{1}$ Data obtained only in the $2 \mathrm{mmol} \mathrm{L}^{-1} \mathrm{~N}$-treatment.

${ }^{2}$ LSD - Least significant difference by Tukey test (0.05).

${ }^{3}$ Non-nodulated.

Table 2 - Number of nodules per plant (NN), nitrogenase activity (N-ase), number of stems (NS), dry matter yield (DM), nitrogen concentration (N), total protein (TP), non-protein N concentration (NPN) and digestibility (Digest) of alfalfa plant samples (average of four replications and four samplings).

\begin{tabular}{|c|c|c|c|c|c|c|c|c|}
\hline Cultivar & NN & $\mathrm{N}$-ase & NS & $\mathrm{DM}$ & $\mathrm{N}$ & $\mathrm{PB}$ & NPN & Digest \\
\hline & & $\mu \mathrm{mol} \mathrm{L} \mathrm{L}^{-1} \mathrm{~h}^{-1}$ plant $^{-1}\left(\mathrm{C}_{2} \mathrm{H}_{2}\right)$ & $0.1 \mathrm{~m}^{-2}$ & $\mathrm{Mg} \mathrm{ha}^{-1}$ & \multicolumn{4}{|c|}{ - } \\
\hline Crioula Brasileira & $37 \mathrm{a}$ & $350 \mathrm{a}$ & $48 \mathrm{~b}$ & $2.72 \mathrm{a}$ & $3.65 \mathrm{~b}$ & $20.62 \mathrm{~b}$ & $1.01 \mathrm{~b}$ & $70.42 \mathrm{~b}$ \\
\hline Crioula Chilena & $28 \mathrm{a}$ & 369 a & $49 \mathrm{~b}$ & $2.57 \mathrm{ab}$ & $3.63 \mathrm{~b}$ & $20.91 \mathrm{~b}$ & $0.99 \mathrm{~b}$ & $71.11 \mathrm{~b}$ \\
\hline Pioneer 5454 & $41 \mathrm{a}$ & $537 \mathrm{a}$ & 53 a & $2.06 \mathrm{c}$ & $4.19 \mathrm{a}$ & $23.19 \mathrm{a}$ & $1.17 \mathrm{a}$ & $74.86 \mathrm{a}$ \\
\hline CUF-101 & 36 a & 317 a & $44 \mathrm{c}$ & $2.44 \mathrm{~b}$ & $3.69 \mathrm{~b}$ & $20.48 \mathrm{~b}$ & $0.89 \mathrm{~b}$ & $70.30 \mathrm{~b}$ \\
\hline $\operatorname{LSD}^{(1)}$ & 19 & 274 & 3.47 & 0.21 & 0.21 & 0.90 & 0.17 & 1.55 \\
\hline $450 \mathrm{~kg} \mathrm{~N} \mathrm{ha}^{-1}$ year $^{-1}$ & $20 \mathrm{~b}$ & $215 \mathrm{~b}$ & $49 \mathrm{a}$ & $2.53 \mathrm{a}$ & $3.83 \mathrm{a}$ & $21.29 \mathrm{a}$ & $1.05 \mathrm{a}$ & $71.72 \mathrm{a}$ \\
\hline (biological fixation) & $51 \mathrm{a}$ & 571 a & $48 \mathrm{a}$ & $2.37 \mathrm{a}$ & $3.74 \mathrm{a}$ & $21.31 \mathrm{a}$ & $0.98 \mathrm{a}$ & $71.63 \mathrm{a}$ \\
\hline $\mathrm{LSD}^{(1)}$ & 10 & 146 & 1.86 & 0.16 & 0.12 & 0.52 & 0.07 & 0.82 \\
\hline $\mathrm{CV} \%$ & 43.9 & 57.5 & 11.0 & 1.3 & 4.39 & 3.32 & 9.48 & 1.57 \\
\hline
\end{tabular}

${ }^{(1)}$ LSD - Least significant difference by Tukey test $(0.05)$.

useful in comparative situations among treatments in a given experiment (Somasegaram \& Hoben, 1995). The observed difference $(P<0.05)$ indicated that the nitrogen biological fixation potential activity was impaired by the presence of the nitrogen fertilizer. There is a close relation between nodule number and enzyme nitrogenase activity (Vincent, 1975; Tsai et al., 1993).

Regarding the number of stems, nitrogen content, crude protein and non-protein nitrogen content, the cultivar Pioneer-5454, characterized by prostrated growth habit and dormancy degree 3 , presented superior performance in comparison to the other cultivars, but showed lower dry matter production (Table 2). Nitrogen concentration showed inverse relation with the dry matter production under field conditions, indicating a dilution effect resulting of cultivar's differences in growth and yield
(Teuber et al., 1984). The ‘Crioula Brasileira’ presented a little higher dry matter production compared to the other cultivars, but superior to cultivars CUF-101 and Pioneer 5454 ( $P>0.05)$. Except for 'Pioneer-5454', all other cultivars showed the same dormancy degree (group 9) and had similar origin, specially 'Crioula Chilena' and Crioula Brasileira' cultivars, whose differences are the employed technology and the seed production origin ('Crioula brasileira' from Chapecó, SC, Brazil, and "Crioula Chilena' from Chile).

CUF-101 cultivar showed the worst performance, regarding number of stems and dry matter production, as already reported in the literature in studies with the same cultivars (Oliveira, 1986; Passos, 1994; Botrel \& Alvim, 1994; Anchão, 1995; Monteiro et al., 1998). Another relevant observation of these authors is the high fiber con- 
tent found in the CUF-101 cv stems. Although this characteristic was not evaluated in the present research, apparently it did not influence the results, once the total digestibility was similar among the tested cultivars. The nitrogen fertilization was not enough to enhance the number of stems, dry matter production, nitrogen-, crude protein-, non-protein nitrogen contents and digestibility (Table 2). The symbiosis between alfafa /Sinorhizobium meliloti showed to be adequate to supply the nitrogen needed by the plant, corresponding to $450 \mathrm{~kg} \mathrm{~N}^{-1}$ year ${ }^{-1}$. Under controlled conditions the $2 \mathrm{mmol} \mathrm{L}^{-1}$ of $\mathrm{N}$ in the solution induced symbiosis establishment and activity. In the field, the $0.17 \%$ total $\mathrm{N}$ content in the soil surface layer $(0$ to $20 \mathrm{~cm}$ ) could have supplied the initial needs of the alfalfa plant.

Results referring to the non-protein nitrogen content presented the same tendency of that obtained for the nitrogen content and crude protein. It was expected that the nitrogen fertilization would cause increase in the non-protein nitrogen content, compared to the biological nitrogen fixation as observed by other authors (Teuber \& Phillips, 1988; Cherney et al., 1994). Besides the additional cost, the use of nitrogen fertilizers, according to these authors, can induce a stand decrease due to plagues and weeds attack, and still cause a decrease in the forage nutritional quality due to nitrate accumulation. The applied $45 \mathrm{~kg} \mathrm{~N}^{-1}$ in each cut did not cause any nitrate accumulation excess. The nitrogen conversion metabolism inside the plant was enough to convert the absorbed nitrogen, once the applied molybdenum, a co-factor of the nitrate reductase enzyme, intensified the reduction process of the absorbed nitrate, promoting thus the utilization of the mineral nitrogen.

There was no variation in the crude protein content between the studied nitrogen sources $(P>0.05)$. Nitrogen source did not affect the dry matter in vitro digestibility. 'Pioneer 5454' presented higher protein values and also higher digestibility, while the other cultivars presented similar results. Nitrogen content in the dry matter was positively related to the digestibility.

\section{CONCLUSIONS}

Differently of the results obtained under controlled conditions, alfalfa nitrogen fertilization in the field (450 kg ha- ${ }^{-1}$ year ${ }^{-1}$ ) did not provide yield and nutritive value increases in comparison to inoculation with the bacteria Sinorhizobium meliloti. Therefore, alfalfa nitrogen fertilization is not recommended, since this crop species is properly inoculated with Sinorhizobium meliloti efficient strain. 'Crioula Brasileira' and 'Crioula Chilena' were the better yielding cultivars while 'Pioneer-5454' revealed better nutritive value in the produced biomass.

\section{REFERENCES}

ANCHÃO, P.P.A. Interação microbiológica de fungicidas no tratamento de sementes de alfafa visando a redução da taxa de semeadura. Piracicaba: USP/ESALQ, 1995. 84p. (Dissertação - Mestrado).

ARAÚJO, R.S.; HUNGRIA, M. (Ed.) Microrganismos de importância agrícola. Brasília: EMBRAPA, CNPAF; CNPSo, 1994. 236p. (Documentos, 44).

BEKBULATOV, R.M.; KUNICHNIKOVA, I.N.; BORISEVICH, V.K.; POSYPANOV, G.S. Effects of different rates of nitrogeneous fertilizers and granulometric composition of soil on symbiosis activity and plant productivity of alfalfa and red clover. Izvetiya Timirazevskoi Selakokhozyaisvennoi Akademii, v.1, p.102, 1998.

BOTREL, M. de A.; ALVIM, M.J. Avaliações preliminares de alfafa, na região da zona da mata de Minas Gerais. In: WORKSHOP SOBRE O POTENCIAL FORRAGEIRO DA ALFAFA (Medicago sativa L.) NOS TRÓPICOS, Juiz de Fora, 1994. Anais. Juiz de Fora: EMBRAPA, CNPGL, 1994. p.37-46.

CHERNEY, D.J.R.; CHERNEY, J.H.; PELL, A.N. Inorganic nitrogen supply effects on alfalfa forage quality. Journal of Diary Science, v.77, p.230236, 1994.

CIHACEK, L.J. Alfalfa nutrient needs and fertilization. In: WORKSHOP SOBRE O POTENCIAL FORRAGEIRO DAALFAFA (Medicago sativa L.) NOS TRÓPICOS, Juiz de Fora, 1994. Anais. Juiz de Fora: EMBRAPA, CNPGL, 1994. p.93-97.

FISHBECK, K.A.; HEICHEL, G.H.; VANCE, C.P. Dry matter, nitrogen distribution and nitrogen fixation in contrasting alfalfa symbioses. Crop Science, v.27, p.1205-1209, 1987.

FONTES, P.C.R.; CÓZER, A.C.; MARTINS, C.E.; VILELA, D. Resposta da cultura da alfafa (Medicago sativa L.) à adubação nitrogenada. Revista da Sociedade Brasileira de Zootecnia, v.21, p.996-1001, 1992.

HARDY, R.W.F.; HOLSTEN, R.D.; JACHSON, E.K.; BURNS, R.C. The acetylene-ethilene assay for $\mathrm{N}_{2}$ fixation: Laboratory and field evaluation. Plant Physiology, v.43, p.1185-1207, 1968.

MONTEIRO, A.L.G.; COSTA, C.; SILVEIRA, A.C. Produção e distribuição de matéria seca e composição bromatológica de cultivares de alfafa (Medicago sativa L.) Revista da Sociedade Brasileira de Zootecnia, v.27, p.868-874, 1998.

OLIVEIRA, P.R. Avaliação da produção de feno de alfafa (Medicago sativa L.) Piracicaba: USP/ESALQ, 1986. 75p. (Dissertação - Mestrado).

PASSOS, L.P. Indicadores fisiológicos para a cultura de alfafa. In: WORKSHOP SOBRE O POTENCIAL FORRAGEIRO DA ALFAFA (Medicago Sativa L.) NOS TRÓPICOS, Juiz de Fora, 1994. Anais. Juiz de Fora: EMBRAPA, CNPGL, 1994. p.149-148.

PEREIRA JR., A.; ROSSI JR., P. Manual prático de avaliação nutricional de alimentos. Piracicaba: FEALQ, 1990. 34p.

PHILLIPS, D.A.; TEUBER, L.R.; JUE, S.S. Relationships between apparent nitrogen fixation and carbon exchange rate in alfalfa. Crop Science, v.20, p.491-495, 1982.

PHILLIPS, D.A.; DAKORA, F.D.; SANDE, E.; JOSEPH, C.M.; ZON, J. Synthesis, release and transmission of alfalfa signals to rhizobial sumbionts. Plant and Soil, v.161, p.69-80, 1994.

RACCA, R.; BASIGALUP, D.; BRENZONI, E.; BRUNO, O.; CASTELL, C.; COLLINO, D.; DARDANELLI, J.; DIAZ ZORITA, M.; DUHALDE, J.; GONZALES, N.; HANSEN, W.; HEINS, N.; LAICH, F.; LOPEZ, A.; PERALTA, O.; PERTICARI, A.; QUADRELLI, A.; RIVERO, E.; ROMERO, N.; SERENO, R. Alfalfa symbiotic dinitrogen fixation in the Argentine Pampean Region. In: NORTH AMERICAN ALFALFA IMPROVEMENT CONFERENCE, 36., Bozeman, Montana, 1998. Proceedings. Bozeman, Montana, 1998. p.71.

RASSE, D.P.; SMUCKER, A.J.M. Tillage effects on soil nitrogen and plant biomass in a corn-alfalfa rotation. Journal of Environmental Quality, v.28, p.873-880, 1999.

RAUN, W.R.; JOHNSON, G.V.; PHILLIPS, S.B.; THOMASON, W.E.; DENNIS, J.L.; COSSEY, D.A. Alfalfa yield response to nitrogen applied after each cutting. Soil Science Society of America Journal, v.63, p.1237-1243, 1999.

SÁRRIES, G.A.; ALVES, M.C.; OLIVEIRA, J.C.V. Sanest. Piracicaba: USP/ESALQ; CIAGRI, 1993. 57p. (Série Didática, 6) 
SARRUGE, J.R. Soluções nutritivas. Summa Phytopathologica, v.1, p.231234, 1975.

SAS Institute. SAS user's guide: statistics. version 5. Cary: Statistical Analysis System Institute, 1985.

SOMASEGARAN, P.; HOBEN, H.J. Handbook for Rhizobia. Methods in legume Rhizobia technology. New York: Springer-Verlag, 1995.

SPAINK. H.P. Rhizobial lipo-oligosaccharudes: answers and questions. Plant Molecular Biology, v.20, p.977-986, 1992.

STOUT, W.L.; FALES, S.L.; MULLER, L.D.; SCHNABEL, R.R.; WEAVER, S.R. Water quality implications of nitrate leaching from intensively grazed pasture swards in the northeast US. Agriculture Ecosystems \& Environment, v.77, p.203-210, 2000.

TEUBER, L.R.; PHILLIPS, D.A. Influences of selection method and nitrogen environment on breeding alfalfa for increased forage yield and quality. Crop Science, v.28, p.599-604, 1988.

TEUBER, L.R.; LEVIN, R.P.; SWEENEY, T.C.; PHILLIPS, D.A. Selection for $\mathrm{N}$ concentration and forage yield in alfalfa. Crop Science, v.24, p.553-558, 1984
TSAI, S.M.; SILVA, P.M.; CABEZAS, W.L.; BONETTI, R. Variability in nitrogen fixation of common bean (Phaseolus vulgaris L.) intercropped with maize. Plant and Soil, v.152, p.93-101, 1993.

VINCENT, J.M. Manual practico de rizobiologia. 1.ed. Buenos Aires: Hemisfério Sur, 1975. 200p.

ZHU, Y.P.; SHEAFFER, C.C.; RUSSELLE, M.P.; VANCE, C.P. Dinitrogen fixation of annual Medicago species. In: NORTH AMERICAN ALFALFA IMPROVEMENT CONFERENCE, 35., Oklahoma City, 1996. Oklahoma City, 1996. p.75.

ZHU, Y.P.; SHEAFFER, C.C.; VANCE, C.P.; GRAHAM, P.H.; RUSSELLE, M.P.; MONTEALEGRE, C.M. Inoculation and nitrogen affect herbage and symbiotic properties of annual Medicago species. Agronomy Journal, v.90, p.781-786, 1998.

Received August 08, 2002

Accepted May 14, 2004 